\section{GROUND-BREAKING ORTHODONTICS GRADUATES}

The students in first cohort on the Diploma in Primary Care Orthodontics have received their diplomas at the Royal College of Surgeons of England, the culmination of three years of study.

The ground-breaking Diploma was developed by the Faculty of General Dental Practice (UK) and the British
Orthodontic Society, and is examined jointly with the Faculty of Dental Surgery. It is designed for primary care dentists wishing to enhance their skills in orthodontics, and/or for those wishing to develop a special interest in orthodontics. It also provides the potential for practitioners to progress to a MOrth and specialisation.

\section{TREMENDOUS ITALIAN ACCOLADE FOR NAIRN}

Professor Nairn Wilson, Dean of King's College London Dental Institute, has been honoured by the University of Brescia, Italy, with the conferment of the title of Cultore Della Materia delle discipline Odontostomatologiche, the University's equivalent of Visiting Professor.

Professor Wilson was presented with his scroll at the ninth Anglo-Italian Colloquium held in Brescia between 5-8 May.

'This is a tremendous accolade, which I will greatly treasure,' said Professor Wilson. 'I wish the highly successful, long-established collaboration between the Dental Institute and the Dental School of the University of Brescia every success in the future.'

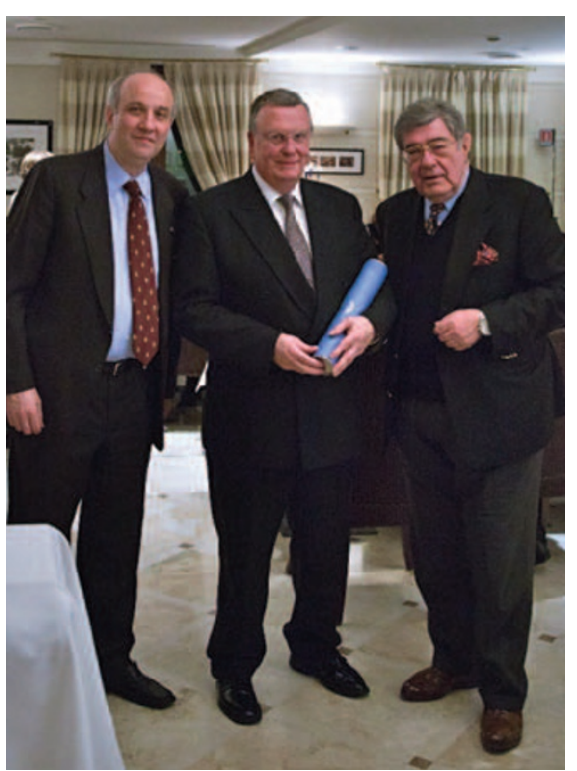

(left to right) Professor Pier Luigi Sapelli, Director of the Dental Clinic, University of Brescia; Professor Nairn Wilson; Professor Corrado Paganelli, Dean of the Dental School, University of Brescia and Chief Dental Officer of Italy

\title{
THE JOHN ZAMET MEMORIAL PRIZE
}

Dr John Zamet was one of the foremost names in periodontology and his legacy of teaching and research is being remembered in a grant now offered to postgraduate students.

It is in memory of Dr Zamet's passion for, and dedication to, periodontology that The John Zamet Memorial Prize in Periodontal Research has been established in association with the Alpha Omega London Chapter and Charitable Trust. The prize provides an enviable opportunity for postgraduate students in the field of periodontology to gain recognition and financial help in the pursuit of their studies, with a
$£ 1,000$ prize being awarded annually. Applications for the award are open to all UK-based postgraduate dental students studying for a Master's degree or $\mathrm{PhD}$ who are undertaking or who have recently completed original research associated with clinical periodontology.

Applicants are invited to submit a covering letter, a letter of support from their research supervisor confirming their supervision of the project, and an abstract not exceeding 1,000 words to the Alpha Omega Trust. The abstract should give brief notes on: the background to the project, aims, methods, relevance to clinical periodontology,

\section{DIARY}

\section{JUNE}

Training essentials - An IRMER

course in dental radiography and

radiation protection

Date: 17 June 2011

Venue: Apex Waterloo Place Hotel, Edinburgh

Telephone: 02075634590

Email: events@bda.org

www.bda.org/events

\section{World Aesthetic Congress}

Date: 17-18 June 2011

Venue: Business Design Centre, Islington

Telephone: 0800371652

www.independentseminars.com/wac

iTOP Introductory: developing proven

strategies that can lead to more effective communication with patients

Date: 17-18 June 2011

Venue: Walton Hall, Warwickshire

Email:info@curaprox.co.uk

www.curaprox.co.uk

BACD Roadshow - A peek into the future of cosmetic dentistry

Date: 20 June 2011

Location: Belfast

Email:suzy@bacd.com

www.bacd.com

BACD Bristol Study Club: Realistic, Fast,

Fixed Cosmetic Orthodontics for GDPs

Date: 30 June 2011

Location: Bristol

Email:suzy@bacd.com

www.bacd.com and start and completion dates (or estimated completion date). Application is by three paper copies and an electronic copy, submitted by 31 December 2011 to: Professor Andrew Eder, Chairman, The Alpha Omega London Charitable Trust, 2nd floor, 57a Wimpole Street, London W1G 8YP. andreweder@ restorative-dentistry.co.uk

Applications will be assessed and decided upon by a panel of at least two Specialists in Periodontology of Professorial/Consultant status and the winner of the prize will have the opportunity to present the results and/ or clinical implications of the research at a lecture meeting of the Alpha Omega London Chapter. 